\title{
Correlation of Phenotypic and Genetic Heterogeneity in Cystic Fibrosis: Variability in Sweat Electrolyte Levels Contributes to Heterogeneity and is Increased With the XV-2c/KM19 B Haplotype
}

\author{
Michal Witt, Robert P. Erickson, Carole Ober, William F. Howatt, and Rosann Farber \\ Departments of Human Genetics (M.W., R.P.E.) and Pediatrics and Communicable Diseases (M.W., R.P.E., W.F.H.), \\ University of Michigan, Ann Arbor; and Molecular Genetics Laboratory, Department of Obstetrics and Gynecology, \\ University of Chicago (C.O., R.F.), Illinois
}

We have reinvestigated a classification of clinical heterogeneity among cystic fibrosis (CF) patients that we previously reported and investigated the possible relationship of the identified CF subgroups to haplotypes around the CF gene and to HLA-DR haplotypes. Age-corrected values for sweat electrolytes, rate of progression of lung disease as assessed by Brasfield chest $x$-ray scores, and severity of pancreatic insufficiency as assessed by daily supplemented enzyme dosage were obtained for 55,59 , and 59 patients, respectively. XV-2c and KM19 RFLPs were determined by hybridization to TaqI and PstI digests of human genomic DNA, respectively, and analysis of mutations by PCR amplification followed by allele-specific oligo-deoxynucleotide hybridization was performed for 29 patients. HLA-DR restriction fragment length polymorphisms (RFLPs) were determined by hybridization of cDNA $\beta 1$ and genomic $D Q \alpha$ probes to TaqI digests of human genomic DNA. The results show that the previous subdivision on the basis of age-corrected levels of sweat electrolytes, as well as measures of severity of lung disease and pancreatic disease, is valid. In addition, the $\mathrm{C}$ and D haplotypes are associated with lower agecorrected sweat sodium level. No significant relationship between $\mathrm{CF}$ haplotypes and the other two disease variables or between HLA. DR haplotypes and any of the clinical variables was found.

Received for publication December 22, 1989; revision received July 30, 1990

Address reprint request to Robert P. Erickson, Dept. of Pediatrics, University of Arizona Health Sciences Center, Tucson, AZ 85724 .

Rosann Farber's current address is Dept. of Pathology, University of North Carolina, CB 7525, Chapel Hill, N.C. 27599; Michal Witt's current address is Institute of Human Genetics, Polish Academy of Sciences, 60-479 Poznan, Poland.
KEY WORDS: HLA-DR, pancreatic disease, haplotype association

\section{INTRODUCTION}

Cystic fibrosis (CF) is the most common autosomal recessive disorder in Caucasians, affecting about one in 2,500 live births, with a carrier frequency of one in 25 . The basic defect in CF is probably a genetic alteration in the control of chloride transport [Quinton and Bigman, 1983; Welsh and Liedtke, 1988]. The CF gene was at first mapped to chromosome 7 band q21-31 by linkage to multiple DNA markers [Knowlton et al., 1985; Scambler et al., 1988; Tsui et al., 1985; Wainwright et al., 1985; White et al., 1985] and recently has been cloned and partially characterized [Rommens et al., 1989; Riordan et al., 1989; Kerem et al., 1989c], with results suggesting that there is a probable defect in chloride transport. The presenting clinical symptoms of the disease are related mainly to chronic obstructive pulmonary involvement and malfunction of exocrine glands, leading to pancreatic enzyme insufficiency and elevation of sodium and chloride ions in sweat [Wood et al., 1976]. The considerable heterogeneity of clinical manifestations of CF is well documented. This phenomenon might reflect genetic heterogeneity of the disorder; e.g., differences among patients for features such as pancreatic function [Kerem et al., 1989a] and meconium ileus [Kerem et al., 1989b; Mornet et al., 1988, 1989] seem to be genetically determined. Also the distribution of haplotypes recognized by various molecular probes varies in different populations studied [Cutting et al., 1989; Devoto et al., 1989; Estivill et al., 1987a; Stern et al., 1976], which also suggests genetic heterogeneity.

In a previous study from this laboratory, different combinations of primary clinical variables were used for subgrouping individuals affected with CF (Sing et al., 1982]. Four distinct subgroups (clusters) of individuals who varied in their laboratory values and clinical course of the disease were identified. This heterogeneity was 
based on three age corrected variables: sweat sodium level, pancreatic enzyme dosage, and severity of lung disease as judged by chest $\mathrm{x}$-ray scores. It was shown that the information contributed by the sweat level to the clinical heterogeneity of CF patients separated clusters 1 and 2 from clusters 3 and 4 and was independent of the relationship between pancreatic damage and pulmonary function (which separated clusters 1 and 3 from clusters 2 and 4).

In the present study, the same set of clinical variables was used on a set of new patients to reappraise the original separation criteria and to search for correlations of clinical status of CF patients with four haplotypes recognized by probes XV-2c and KM19, which show significant linkage disequilibrium with the $\mathrm{CF}$ mutation [Estivill et al., 1987a, 1987b]. Because of the high incidence of diabetes (which has known HLA associations) in patients with CF [Knowles and Fernald, 1988; Rodman et al., 1986], variable reports of a nonrandom distribution of HLA-specificities in CF patients [Kaiser et al., 1977; Hennequet et al., 1978; Herrod et al., 1979; Polymenidis et al., 1973], and the suggestion of a role of autoimmunity in this disorder [Geffner et al., 1988; Wilkin et al., 1987], we also screened part of our study group for HLA-Dr haplotypes [Cox et al., 1988].

\section{MATERIALS AND METHODS}

A sample of 59 individuals of Caucasian origin affected with CF was studied. Forty-two were patients at the Mott Children's Hospital of the University of Michigan in Ann Arbor; 17 were from Wyler Children's Hospital, The University of Chicago, and Children's Memorial Hospital, Northwestern University of Chicago. Clinical data were collected by physicians in CF clinics. Sweat sodium levels were available for 55 individuals. Only levels higher than $70 \mathrm{mEq} / \mathrm{L}$ were considered to support a $\mathrm{CF}$ diagnosis. Pulmonary involvement was measured by chest x-ray severity score using the Brasfield scoring system. However, pulmonary damage was classified as one of four discrete classes ranging from 1 (the least severe, Brasfield score 19-25) to 4 (the most severe, Brasfield score 1-6). The Brasfield score was available for 59 individuals. GI tract involvement was quantitated in terms of the dosage of pancreatic enzyme supplementation. The standard enzyme dose was expressed in terms of equivalent number of Pancrease capsules per day. The relative medication strength based on lipase content was as follows: Pancrease 4, Cotazym and Cotazym S 5, Creon 8, and Zymase 12. The equivalent Pancrease dose was arrived at by the equation: Pancrease dose $=$ (medication strength $\times$ number of capsules a day) / 4. Enzyme dosage was available in 59 cases.

The deviation of an individual's age at exam from the average of all exam ages for those who share this grade of pulmonary involvement was taken as an age-corrected measure of pulmonary severity. Individuals with positive deviations, regardless of their severity rating for the pulmonary variable, are assumed to be experiencing a less severe course of the disease than those who deviate negatively. Sweat sodium levels were adjusted by linear regression to average age of diagnosis. Pancreatic enzyme dosage was also adjusted by linear regres- sion for age at current dose. Age-corrected measures of "severity" for all three variables were then used in all analyses, rather than contrasting the severity rating directly (since severity is so age dependent). To compare principal components of the old and new study, two approaches were used. The first was the angular comparison of eigenvectors of principal components from both studies. In the second approach, new principal component scores, based on the previous study, were created by including new data into functions L1, L2, and L3 of Sing et al. [1982]. The bivariate scatter of L2 and L3 was plotted and cutpoints from the previous study were used to check the clustering within the new sample of $\mathrm{CF}$ individuals.

For restriction fragment length polymorphisms (RFLP) analyses, human genomic DNA was isolated from a 5-30 ml sample of whole blood according to the method of Kunkel et al. [1977] with a slight modification. Routinely, $5 \mu \mathrm{g}$ of DNA was digested with restriction enzyme according to manufacturer's protocols, electrophoresed through $0.9 \%$ agarose in tris-borate buffer, and transferred to Hybond-N membrane (Amersham) in $10 \times \mathrm{SSC}$. The filters were hybridized in $1 \mathrm{M} \mathrm{NaCl}, 1 \%$ SDS, $10 \%$ dextran sulphate, overnight at $65^{\circ} \mathrm{C}$. Molecular probes were labeled by oligolabelling method [Feinberg and Vogelstein, 1984]. Filters were washed to final stringency of $1 \times \mathrm{SSC}$ at $65^{\circ} \mathrm{C}$ and exposed to Kodak XAR film at $-70^{\circ} \mathrm{C}$ with intensifying screens (Dupont Cronex Lightening-Plus). Molecular probes XV-2c and KM19 [Estivill et al., 1987a, 1987b], recognizing RFLPs within TaqI and $P$ stI digests, respectively, were used. These probes, obtained from Dr. Robert Williamson, were used to determine haplotypes for family counseling, and subsequently the data were used for this study. Haplotypes were named according to a published nomenclature [Beaudet et al., 1988].

For HLA-DR typing on DNA, a cDNA $\beta 1$ probe [Long et al., 1983] and a genomic $\mathrm{DQ} \alpha$ probe [Trowsdale et al., 1983], obtained from Dr. Richard Spielman, were used. Filters with TaqI digests of CF families' DNA samples served for the detection of band patterns specific for 18 different $D R$ antigen types and their combinations [Cox et al., 1988]. Following hybridization, the filters were washed to a final stringency of $0.1 \times \mathrm{SSC}$ at $65^{\circ} \mathrm{C}$. In cases in which the pattern shared by antigens DR7 and/or DRw9-which are indistinguishable with probes $\mathrm{DR} \beta 1$ and $\mathrm{DQ} \alpha$ in TaqI digests, were detected-the haplotypes were all arbitrarily classified as DR7. This is justified by a very low frequency of DRw9 in Caucasians [Cox et al., 1988]. Complete DR antigen type data were available for $33 \mathrm{CF}$ patients.

In order to detect the $\Delta$ F508 mutation, DNA was amplified using the polymerase chain reaction (PCR); $1 \mu \mathrm{M}$ each of primers C16B and C16D [Kerem et al, 1989c, 1989d], which flank the region containing the mutation, was used with $1 \mu \mathrm{g}$ genomic DNA and 2.5 units Taq polymerase in a total volume of $100 \mu 1$. Annealing conditions were 45 seconds at $62^{\circ} \mathrm{C}$, extension was 2 minutes at $72^{\circ} \mathrm{C}$, and denaturation was 1 minute at $94^{\circ} \mathrm{C}$ for a total of 30 cycles. Then $5 \mu$ l of amplified product were denatured in $0.4 \mathrm{~N} \mathrm{NaOH}$, added to $0.2 \times$ $\mathrm{SSC}$, and dot-blotted to nylon membranes. 
The $\Delta$ F508 mutation was detected using sequence specific oligonucleotides (SSOs) for the mutated (oligo- $\Delta \mathrm{F}$ ) and the normal sequence (Oligo-N) [Kerem et al., 1989c]. SSOs were end-labelled with gamma- $\left({ }^{32} \mathrm{P}\right)$ ATP and hybridized to filter-bound DNA for 12 hours at $42^{\circ} \mathrm{C}$ in $0.5 \mathrm{M} \mathrm{NaCl}, 50 \mathrm{mM} \mathrm{NaPO}{ }_{4}, 1 \%$ SDS, $5 X$ Denhardts, and $200 \mu \mathrm{g} / \mathrm{ml}$ salmon sperm DNA. Membranes were washed twice at room temperature for 30 minutes in $5 \times \mathrm{SSC}$ and $1 \%$ SDS and once at $65^{\circ} \mathrm{C}$ for 30 minutes each in $2 \times$ SSC and 1\% SDS. Hybridization was visualized by an autoradiograph.

\section{RESULTS}

In order to check the effect of particular XV-2c/KM19 haplotypes on the three clinical variables studied, the percent distribution of haplotypes $\mathrm{A}, \mathrm{B}, \mathrm{C}, \mathrm{D}$, and combined haplotypes $\mathrm{A}+\mathrm{B}, \mathrm{A}+\mathrm{C}, \mathrm{B}+\mathrm{D}, \mathrm{C}+\mathrm{D}$ (not shown) in negative and positive deviation groups has been calculated for the group of 59 patients. An analysis of variance using average deviation in sweat sodium levels, average age deviation from x-ray age class, and average deviation in pancreatic enzyme dose was performed. The values for heterozygous individuals were assigned 50:50 to each allele. The results are shown in Tables I-III. The difference in sweat sodium levels for a group of patients with combined haplotypes A + B vs. a group with combined haplotypes $\mathrm{C}+\mathrm{D}$ is significant at $P<.05$ (Table I, analysis of variance). None of the differences in $\mathrm{x}$-ray severity (Table II) nor pancreatic sufficiency (Table III) are statistically significant.

After this analysis was completed, the CF gene was cloned and the $\Delta F 508$ mutation was found to be the most common mutation, explaining $75 \%$ of $\mathrm{CF}$ mutations [Kerems et al., 1989c]. The $\Delta$ F508 mutation is most commonly associated with the B haplotype and the B haplotype preferentially carries this mutation (although not in Ashkenazi Jewish populations). In order to see whether or not the B haplotypes of our patients predominately carried the $\triangle$ F508 mutation, PCR amplification and allele-specific oligodeoxynucleotide hybridization was performed on the 29 patients for whom DNA samples were still available. As seen in Table IV, the majority of $\mathrm{BB}$ homozygotes were homozygous for $\Delta \mathrm{F} 508$, and $76.8 \%$ of B haplotypes were associated with the $\Delta F 508$ mutation, whereas the $\Delta F 508$ mutation was associated with other haplotypes only $37.5 \%$ of the time in our patient population. (We have assumed that the $\Delta F 508$ mutation was associated with the B haplotype in $\mathrm{B}$ heterozygous, $\triangle \mathrm{F} 508$ heterozygous individuals.)

A subgroup of 33 individuals (all from the University of Michigan) was HLA-DR typed. An example of a Southern blot with several HLA-DR types patterns is

TABLE I. Sweat Sodium/Age at Diagnosis

\begin{tabular}{|c|c|c|c|c|c|c|}
\hline \multicolumn{7}{|c|}{ Percent of haplotypes in deviation group } \\
\hline Deviation & & A & B & $\mathrm{C}$ & D & Total \\
\hline Negative & & 8.06 & 70.97 & 6.45 & 14.52 & 52.54 \\
\hline Positive & & 17.86 & 75.00 & 0.00 & 7.14 & 47.46 \\
\hline & $\begin{array}{l}\mathrm{G} \\
\mathrm{P}\end{array}$ & & & & & \\
\hline \multicolumn{7}{|c|}{ Analysis of variance: haplotype effect } \\
\hline & $\mathrm{N}$ & Mean & DF & $P$ & & \\
\hline A & 14 & 2.37 & 3 & 0.0998 & & \\
\hline B & 80 & 1.02 & & & & \\
\hline $\mathrm{C}$ & 4 & -12.35 & & & & \\
\hline $\mathrm{D}$ & 12 & -5.44 & & & & \\
\hline$A+B$ & 94 & 1.22 & 1 & 0.0150 & & \\
\hline $\mathrm{C}+\mathrm{D}$ & 16 & -7.17 & & & & \\
\hline$A+C$ & 18 & -0.90 & 1 & 0.5177 & & \\
\hline$B+D$ & 92 & 0.18 & & & & \\
\hline
\end{tabular}

TABLE II. Age Deviation/X-ray Class

\begin{tabular}{|c|c|c|c|c|c|c|}
\hline \multicolumn{7}{|c|}{ Percent of haplotypes in deviation group } \\
\hline Deviation & & A & B & $\mathrm{C}$ & D & Total \\
\hline Negative & & 11.43 & 77.14 & 4.29 & 7.14 & 59.32 \\
\hline Positive & \multicolumn{2}{|c|}{$\begin{array}{l}G=3.38 \\
P=0.337\end{array}$} & 66.67 & 2.08 & 16.67 & 40.68 \\
\hline \multicolumn{7}{|c|}{ Analysis of variance: haplotype effects } \\
\hline & $\mathrm{N}$ & Mean & DF & $P$ & & \\
\hline A & 15 & 4.81 & 3 & 0.2912 & & \\
\hline B & 86 & -1.06 & & & & \\
\hline $\mathrm{C}$ & 4 & -0.21 & & & & \\
\hline $\mathrm{D}$ & 13 & 1.50 & & & & \\
\hline$A+B$ & 101 & -0.18 & 1 & 0.7291 & & \\
\hline $\mathrm{C}+\mathrm{D}$ & 17 & 1.10 & & & & \\
\hline$A+C$ & 19 & 3.75 & 1 & 0.5600 & & \\
\hline $\mathrm{B}+\mathrm{D}$ & 99 & -0.72 & & & & \\
\hline
\end{tabular}


TABLE III. Enzyme Dose/Age When First Given Medication

\begin{tabular}{|c|c|c|c|c|c|c|}
\hline \multicolumn{7}{|c|}{ Percent of haplotypes in deviation group } \\
\hline Deviation & & $\mathrm{A}$ & B & $\mathrm{C}$ & $\mathrm{D}$ & Total \\
\hline Negative & & 16.67 & 65.15 & 4.55 & 13.64 & 55.93 \\
\hline \multicolumn{7}{|c|}{$\begin{array}{l}G=4.75 \\
P=0.191\end{array}$} \\
\hline \multicolumn{7}{|c|}{ Analysis of variance: haplotype effects } \\
\hline & $\mathrm{N}$ & Mean & $\mathrm{DF}$ & $P$ & & \\
\hline A & 15 & -1.81 & 3 & 0.2495 & & \\
\hline $\mathrm{B}$ & 86 & 1.10 & & & & \\
\hline $\mathrm{C}$ & 4 & -10.30 & & & & \\
\hline $\mathrm{D}$ & 13 & -2.05 & & & & \\
\hline$A+B$ & 101 & 0.67 & 1 & 0.1401 & & \\
\hline $\mathrm{C}+\mathrm{D}$ & 17 & -3.99 & & & & \\
\hline $\mathrm{A}+\mathrm{C}$ & 19 & -3.59 & 1 & 0.1576 & & \\
\hline$B+D$ & 99 & 0.69 & & & & \\
\hline
\end{tabular}

TABLE IV. Distributions of the $\triangle F 508$ Mutation Among XV-2c and KM19 Haplotypes

\begin{tabular}{cccc}
\hline \multicolumn{4}{c}{$\Delta \mathrm{F508}$} \\
Haplotype & Homozygous & Heterozygous & Negative \\
\hline AA & & 2 & 1 \\
AB & 12 & 3 & 3 \\
BB & 1 & & \\
BC & 3 & 3 & 1 \\
BD & & 3 & \\
\hline
\end{tabular}

shown in Figure 1. Eleven different HLA-DR haplotypes were recognized among these individuals, and the distribution of all of them between clusters $1+2$ and $3+4$, constructed according to Sing et al. [1982], was evaluated (Table V). The distribution of HLA-DR types in the sample studied (66 haplotypes) is not different from a random distribution among the cluster subgroup. Table VI presents the same analysis as in Table V, but the distribution of HLA-DRw6 (the only candidate for participation in heterogeneity as shown in Table V) was run against all other types pooled together. These differences also are not statistically significant.

We have compared principal components analyses of the group of individuals studied currently with the group of individuals described before by Sing et al.|1982]. The principal components obtained for a group of 42 individuals (from University of Michigan Medical Center only) were: $\mathrm{L} 1=-0.68$ (sweat) +0.41 (dose) +0.61 (x-ray age) L2 $=0.10$ (sweat $)+0.88$ (dose) -0.47 (x-ray age) L3 $=0.73$ (sweat) +0.25 (dose) + 0.64 (x-ray age)

The third of these orthogonal functions (L3) is a general measure of the degree of involvement of the three; the first and second are functions that contrast sweat sodium level with enzyme dose and x-ray age (L3), and $x$-ray age with sweat and enzyme dose values (L2). Angular comparisons of these eigenvectors with those previously published [Sing et al., 1982] are given in Table VII. Angles near 20 or less indicate a close relationship between eigenvectors [Pimentel, 1979]. This comparison shows a close relationship between eigenvectors of component 3 from this study to component 1 of the pre-

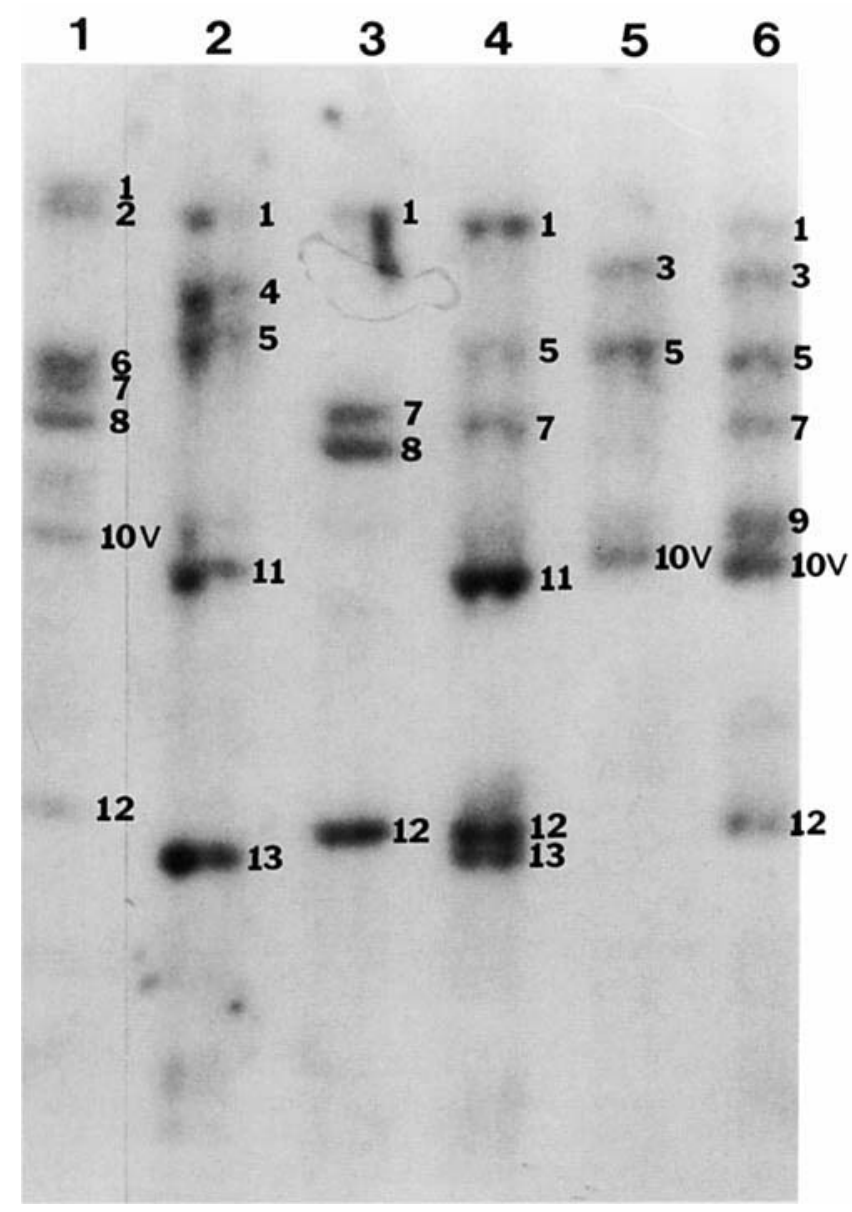

Fig. 1. TaqI DNA patterns detected with the DR $\beta$ probe in six CF patients. Lane 1, DR4/5a; lane 2, DR7b/w8; lane 3, DR4; lane 4, DR7b/ w9a; lane 5, DR3a and/or DRw6a; lane 6, DR3a/w9a or DRw6a/w9a. The filter was subsequently probed with $\mathrm{DQ} \alpha$ probe to discriminate between specificities DR3 and DRw6 (lanes 5 and 6). 
TABLE V HLA-DR Types in Cluster Groups*

\begin{tabular}{lccc}
\hline & \multicolumn{2}{c}{ Cluster group } & \\
\cline { 2 - 4 } HLA & $1+2$ & $3+4$ & Total \\
\hline DN1A & 1 & 0 & 1 \\
w10 & $1.52 \%$ & $0.00 \%$ & $1.52 \%$ \\
& 3 & 1 & 4 \\
w6 & $4.55 \%$ & $1.52 \%$ & $6.06 \%$ \\
& 9 & 3 & 12 \\
w8 & $13.64 \%$ & $4.55 \%$ & $18.18 \%$ \\
& 1 & 1 & 2 \\
1 & $1.52 \%$ & $1.52 \%$ & $3.03 \%$ \\
& 2 & 3 & 5 \\
2 & $3.03 \%$ & $4.55 \%$ & $7.58 \%$ \\
& 2 & 1 & 3 \\
3 & $3.03 \%$ & $1.52 \%$ & $4.55 \%$ \\
& 8 & 5 & 13 \\
4 & $12.12 \%$ & $7.58 \%$ & $19.70 \%$ \\
& 4 & 4 & 8 \\
5 & $6.06 \%$ & $6.06 \%$ & $12.12 \%$ \\
& 2 & 5 & 7 \\
7 & $3.03 \%$ & $7.58 \%$ & $10.61 \%$ \\
& 6 & 4 & 10 \\
8 & $9.09 \%$ & $6.06 \%$ & $15.15 \%$ \\
& $0.00 \%$ & 1 & 1 \\
$* \mathrm{G}=7.570 ; \mathrm{DF}$ & $10 ; P=0.671$. & & $1.52 \%$ \\
& & &
\end{tabular}

TABLE VI. HLA-DRw6 Vs. Other Types in Cluster Groups*

\begin{tabular}{|c|c|c|c|}
\hline \multirow[b]{2}{*}{ HLA } & \multicolumn{2}{|c|}{ Cluster group } & \multirow[b]{2}{*}{ Total } \\
\hline & $1+2$ & $3+4$ & \\
\hline Others & $\begin{array}{l}29 \\
43.94 \%\end{array}$ & $\begin{array}{l}25 \\
37.88 \%\end{array}$ & $\begin{array}{l}54 \\
81.82 \%\end{array}$ \\
\hline w6 & $\begin{array}{c}9 \\
13.64 \%\end{array}$ & $\begin{array}{l}3 \\
4.55 \%\end{array}$ & $\begin{array}{l}12 \\
18.18 \%\end{array}$ \\
\hline
\end{tabular}

${ }^{*} \mathrm{G}=1.823 ; \mathrm{DF}=1 ; P=0.177$.

TABLE VII. Angular Comparison of Principal Components of Old and New Michigan Data

\begin{tabular}{lcccc}
\hline & \multicolumn{4}{c}{ Old components $^{\mathrm{a}}$} \\
\cline { 2 - 5 } & & 1 & 2 & 3 \\
\hline New & 1 & 86 & 135 & $10^{*}$ \\
Michigan & 2 & 75 & 109 & 84 \\
Data & 3 & $15^{*}$ & 128 & 95 \\
\hline
\end{tabular}

a Sing et al. [1982].

* Indicates close relationship.

vious study and of component 1 of this study to component 3 of Sing et al. [1982]. When the group of 17 individuals diagnosed in other medical centers (Chicago) was included in this analysis, the orthogonal functions accounting for variability represented by the three analyzed variables were as following: $\mathrm{L} 1=0.67$ (sweat) 0.73 (dose) +0.12 (x-ray age) L2 $=-0.42$ (sweat) $0.25($ dose $)+0.87$ (x-ray age $) \mathrm{L} 3=0.61$ (sweat) +0.64 $($ dose $)+0.47$ (x-ray age)

Functions L1, L2, and L3 account for $36 \%, 34 \%$, and $29 \%$, respectively, of the total variability represented by the three variables. In angular comparisons of eigenvectors with the previous results of Sing et al. [1982], only component 3 of pooled data shows a close relationship to the previous component 1 (Table VIII).

\section{DISCUSSION}

There have been many reports on genetic heterogeneity in CF. Several studies of allelic association with DNA markers have shown that the degree of pancreatic involvement (pancreatic sufficiency vs. pancreatic insufficiency) is genetically determined and is associated with different mutant alleles [Devoto et al., 1989; Kerem et al., 1989a; Gasparini et al., 1990]. It has been shown also that American black CF patients, having milder lung disease and more severe GI tract complications [Stern et al., 1976], have a haplotype distribution that is different from Caucasian CF patients [Cutting et al., 1989]. These results are in agreement with the general assumption that different clinical symptoms in CF could be determined by different mutant CF alleles. Extended haplotype data based on DNA markers closely linked to the putative disease gene locus [Kerem et al., 1989c] shows that the most common haplotype correlates well with the $\Delta \mathrm{F} 508,3$-bp deletion (present in approximately $75 \%$ of $\mathrm{CF}$ cases) and with the occurrence of pancreatic insufficiency. The remainder of CF mutant gene pool consists of multiple, different haplotypes which may each be associated with different mutations, and a minor fraction of mutant alleles (approximately 8\%) may be related to better pancreatic function in a group of patients who are pancreatic sufficient. Data have also been reported on different allelic frequencies in CF families with and without meconium ileus [Mornet et al., 1988,1989 ], but they were not confirmed by other authors [Kerem et al., 1989a, 1989b]. When black and Caucasian groups of CF patients were screened separately, the presence of particular haplotypes was not found to be significantly associated with more severe lung disease [Cutting et al., 1989].

In this study a sample of $59 \mathrm{CF}$ patients was studied. Frequencies of haplotypes A, B, C, and D recognized by probes XV-2c and KM19 account for $12.7 \%, 72.9 \%, 3.4 \%$, and $11 \%$, respectively, which is in good agreement with data reported by others for Caucasian populations [Beaudet et al., 1988; Estivill et al., 1987a, 1987b; Mornet et al., 1988; Vidaud et al., 1989]. In our data, the $\mathrm{B}$ haplotype is not associated with either a more or less severe course of the disease measured by the three clinical variables used. The only statistically significant differences between haplotypes were found in sweat sodium levels at the age of diagnosis: individuals with $\mathrm{C}$

TABLE VIII. Angular Comparison of Principal Components for Old and New Combined Data

\begin{tabular}{lcccr}
\hline & \multicolumn{4}{c}{ Old components $^{\mathrm{a}}$} \\
\cline { 2 - 5 } & & 1 & 2 & 3 \\
\hline New & 1 & 80 & 63 & 140 \\
Combined & 2 & 87 & 114 & 51 \\
Data & 3 & $10^{*}$ & 142 & 84 \\
\hline
\end{tabular}

a Sing et al. [1982].

* Indicates close relationship. 
and/or D haplotype(s) had a significantly lower sodium concentration (Table I) than individuals with haplotype(s) A and/or B. Since most of the patients were B haplotype, and most of the $B$ haplotypes studied carried the $\Delta$ F508 mutation, this suggests a correlation of higher age-corrected sweat electrolyte levels with this common mutation. Although not statistically significant, the $\mathrm{C}$ haplotype tends to associate with lower pancreatic enzyme dosage corrected for age (Table III). No significant differences were seen in the distribution of haplotypes between patients with less and more severe lung disease (Table II), which confirms the data of others [Cutting et al., 1989].

There have been several attempts previously to check if the CF mutation segregates with specific HLA antigen types [Hennequet et al., 1978; Herrod et al., 1979; Kaiser et al., 1977; Polymenidis et al., 1973]. The general conclusion has been negative as far as class I HLA antigens are concerned. One report showed a statistically significant association of CF with HLA-B18 [Kaiser et al., 1977]. The prevalence of diabetes mellitus in patients with CF ranges from $8 \%$ to $15 \%$ [Knowles et al., 1988]. Clinical characteristics of diabetes in CF patients are typical of neither classic type I nor type II diabetes mellitus. The abnormal insulin secretion in CF patients is probably caused by destruction of pancreatic islets and/or effects of scarification on islet cell secretion or paracrine function. Nevertheless, the high incidence of diabetes in $\mathrm{CF}$ raises a question of the phenomena of autoimmunity which are involved in this disease and, therefore, the involvement of class II HLA antigens in CF. We have screened (at the DNA level) part of our group of patients with regard to HLA-DR, DQ types. In the group of 33 patients, no statistically significant prevalence of particular types was shown (Table V). However, nearly one fifth of patients screened have the HLA-DRw6 allele, which is present in the three most common haplotypes characteristic for insulin-dependent diabetes mellitus (IDDM) [Tuomilehto-Wolf et al., 1989]. The negative results of studies on circulating antibodies to islet cells or to insulin [Geffner et al., 1988; Wilkin et al., 1987] in CF patients point away from a role of autoimmune factors in the pathogenesis of diabetes in cystic fibrosis. The distribution of all class II HLA alleles in the cluster groups (Table V) and the distribution of HLA-DRw6 vs. all other types in these cluster groups (Table VI) has not shown that HLA-DR, DQ types contribute significantly to phenotypic heterogeneity in CF. The lack of statistical significance for these results may be due to the small size of the sample studied and the marked polymorphism of HLA-DR, DQ antigens.

A previous study from this laboratory [Sing et al., 1982] showed that it was possible to group CF patients into four significantly different subgroups using a combination of three clinical variables: degree of pulmonary involvement, sweat sodium level, and pancreatic enzyme dosage. We have again found that age-corrected variations in the concentration of electrolytes in sweat is an important variable for studies of clinical heterogeneity in CF. Indeed, it is the only variable for which we have found a significant haplotype association. When a currently studied group of patients was divided into four clusters using the same set of clinical variables and the same statistical procedures and mathematical criteria of subgrouping, the distribution of XV-2c/KM19 haplotypes within clusters was random and statistically nonsignificant (not shown). It is worth mentioning that the current population was smaller than the previous one (59 vs. 104 individuals), which may well have affected the final result of the analysis. Also, individuals from this study obviously were not the same as those studied previously, although they were from almost identical geographic and ethnic backgrounds. On the other hand, the principal components which provide a general measure of the degree of involvement of the three clinical variables in heterogeneity were closely related in both studies (Table VIII). When 42 Michigan patients were used for analysis, the similarity between principal components was much higher (Table VII) than when combined data of Michigan and Illinois patients were used (Table VIII). This may be due to subjective differences in the evaluation of clinical status of patients within both groups by their physicians (especially evaluation of chest $x$-ray scores) or due to real genetic differences between these two groups.

In our study, the XV-2c/KM19 B haplotype (strongly associated with the $\Delta$ F508 mutation in our material) appears to be associated with higher levels of sweat electrolytes corrected for age of diagnosis. It is possible that this finding is relevant to the presumed heterozygote advantage of the $\Delta \mathrm{F} 508$ mutation; its frequency in northern European populations is too great to be maintained without a selective advantage. It has been argued that heterozygotes for the CF gene may have lower intestinal losses of electrolytes during enteropathogen-induced diarrhea [Bijman et al., 1988]. Quantitative decreases in heterozygote sweat secretion in response to $\beta$-adrenergic stimulation are compatible with this hypothesis. Since "summer sickness" (gastroenteritis) of small infants led to high infant mortality before fluid/electrolyte therapy was available, a small differential in survival due to the presence of absence of the $\Delta$ F508 mutation could have led to the high carrier frequency.

\section{ACKNOWLEDGMENTS}

The authors thank Susan Farquhar, Lucille Lester, and John Lloyd-Still for help in collecting clinical data and Janice La Pointe for secretarial assistance. We also thank Kim Zerba and Charles Sing for performing statistical analyses and for their critical comments. This work was partly supported by grant Z011 from Cystic Fibrosis Foundation.

\section{REFERENCES}

Beaudet AL, Spence JE, Montes M, O'Brien WE, Estivill X, Farrall M Williamson R (1988): Experience with new DNA markers for the diagnosis of cystic fibrosis. Lancet 1:50-51.

Bijman J, deFonge H, Wine J (1988): Cystic fibrosis advantage. Nature $336: 430$.

Cox NJ, Mela AP, Zmijewski CM, Spielman RS (1988): HLA-DR typing "at the DNA level": RFLPs and subtypes detected with a DR cDNA probe. Am J Hum Genet 43:954-963.

Cutting GR, Antonarakis SE, Buetow KH, Kasch LM, Rosenstein BJ, Kazazian HH, Jr (1989): Analysis of DNA polymorphism haplot- 
ypes linked to the cystic fibrosis locus in North American Black and Caucasian families supports the existence of multiple mutations of the cystic fibrosis gene. Am J Hum Genet 44:307-318.

Devoto M, De Beneditti L, Seia M, Piceni Sereni L, Ferrari M, Bonduelle ML, Malfroot A, Lissens W, Balassopoulou A, Adam G, Loukopoulos D, Cochaux P, Vassart G, Szibor R, Hein J, Grade K, B]erger W, Wainwright B, Romeo G (1989): Haplotypes in cystic fibrosis patients with or without pancreatic insufficiency from four European populations. Genomics, 5:894-898.

Estivill X, Scambler PJ, Wainwright BJ, Hawley K, Frederick P, Schwartz M, Baiget M, Kere J, Williamson R, Farrall M (1987a): Pattern of polymorphism and linkage disequilibrium for cystic fibrosis. Genomics 1:257-263.

Estivill X, Farrall M, Scambler PJ, Bell GM, Hawley KMF, Lench NJ, Bates GP, Kruyer HC, Frederíck PA, Stanier P, Watson EK, Williamson R, Wainwright BJ (1987b): A candidate for the cystic fibrosis locus isolated by selection for methylation-free islands. Nature 326:840-845.

Feinberg AP, Vogelstein B (1984): A technique for radiolabeling DNA restriction endonuclease fragments to high specific activity. Anal Biochem 137:266-267.

Gasparini P, Novelli G, Estivill X, Olivieri D, Savoia A, Ruzzo A, Nunes V, Borgo G, Antonelli M, Williamson R, Pignatti, PF, Dallapiccola B (1990): The genotype of a new linked DNA marker, MP6d-9, is related to the clinical course of cystic fibrosis. J Med Genet 27:17-20.

Geffner ME, Lippe BM, Maclaren NK, Riley WJ (1988): Role of autoimmunity in insulinopenia and carbohydrate derangements associated with cystic fibrosis. J Pediatr 112:419-421.

Hennequet A, Jehanne M, Betuel H, Gilly R, Schmid M, Hors J (1978): Cystic fibrosis and HLA. Tissue antigens 12:159-162.

Herrod HG, Amos DB, Spock A (1979): HLA determinants in families with more than one member with cystic fibrosis. J Pediatr 94:676.

Kaiser GI, Laszlo A, Gyurkovits K (1977): HLA antigens in cystic fibrosis: an association of B18 with the disease. Acta Paediatr Acad Sci Hung 18:27.

Kerem B, Buchanan JA, Durie P, Corey ML, Levison H, Rommens JM, Buchwald M, Tsui L-C (1989a): DNA marker haplotype association with pancreatic sufficiency in cystic fibrosis. Am J Hum Genet 44:827-834.

Kerem E, Corey M, Kerem B, Durie P, Tsui L-C, Levison H (1989b): Clinical and genetic comparisons of patients with cystic fibrosis, with or without meconium ileus. J Pediatr 114:767-773.

Kerem B, Rommens JM, Buchanan JA, Markiewicz D, Cox TK, Chakravarti A, Buchwald M, Tsui L-C, (1989c): Identification of the cystic fibrosis gene: genetic analysis. Science 245:1073-1080.

Kerem B, Rommens JM, Buchanan JA, Markiewicz D, Cox TK, Chakravarti A, Buchwald M, Tsui L-C, (1989d): Erratum, Science 254:1437

Knowles MR, Fernald GW (1988): Diabetes and cystic fibrosis: new questions emerging from increased longevity. J Pediatr 112: 415-416.

Knowlton RG, Cohen-Haguenauer O, Van Cong N, Frezal J, Brown VA, Barker D, Braman JC, Schumm JW, Tsui L-C, Buchwald M, DonisKeiler $H$ (1985): A polymorphic DNA marker linked to cystic fibrosis is located on chromosome 7. Nature 318:380-382.

Kunkel LM, Smith KD, Boyer SH, Borgaonkar DS, Wachtel SS, Miller OJ, Breg WR, Jones HW Jr, Rary JM (1977): Analysis of human Y chromosome-specific reiterated DNA in chromosome variants. Proc Natl Acad Sci USA 74:1245-1249.

Long EO, Wake CT, Gorski J, Mach B (1983): Complete sequence of an HLA-DR chain deduced from cDNA clone and identification of multiple nonallelic DRB chain genes. EMBO J 2:389-394.

Mornet E, Serre JL, Farrall M, Boue J, Simon-bouy B, Estivill X, Willaimson R, Boue A (1988): Genetic differences between cystic fibrosis with and without meconium ileus. Lancet 1:376-378.
Mornet E, Simon-Bouy B, Serre JL, Muller F, Taillandier A, Martinez M, Boue J, Boue A (1989): Genetic heterogeneity between two clinical forms of cystic fibrosis evidenced by familial analysis and linked DNA probes. Clin Genet 35:81-87.

Pimentel RA (1979): "Morphometrics. The Multivariate Analysis of Biological Data." Iowa: Kendall/Hint Publ Comp, p 276.

Polymenidis Z, Ludwig H, Gotz M (1973): Cystic fibrosis and HLA antigens. Lancet 2:1452.

Quinton PM, Bijman J (1983): Higher bioelectric potentials due to decreased chloride absorption in the sweat glands of patients with cystic fibrosis. N Engl J Med 308:1185-1189.

Riordan JR, Rommens JM, Kerem B, Alon N, Rozmahel R, Grzelczak Z, Zielenski J, Lok S, Plavsic N, Chou J-L, Drumm ML, Ianuzzi MC, Collins FS, Tsui L-C (1989): Identification of the cystic fibrosis gene: cloning and characterization of complementary DNA. Science 245:1066-1073.

Rodman HM, Doershuk CF, Roland JM (1986): The interaction of 2 diseases: diabetes mellitus and cystic fibrosis. Medicine 65:389-397.

Rommens JM, Ianuzzi MC, Kerem B, Drumm ML, Melmer G, Dean M, Rozmahel R, Cole JL, Kennedy D, Hidaka N, Zsiga M, Buchwald M, Riordan JR, Tsui L-C, Collins FS (1989): Identification of the cystic fibrosis gene: chromosome walking and jumping. Science 245:1059-1065.

Scambler PJ, Wainwright BJ, Watson E, Bates G, Bell G, Williamson $R$, Farral M (1988): Isolation of a further anonymous informative DNA sequence from chromosome seven closely linked to cystic fibrosis. Nucleic Acids Res 14:1951-1956.

Sing CF, Risser DR, Howatt WF, Erickson RP (1982): Phenotypic heterogeneity in cystic fibrosis. Am J Med Genet 13:179-195.

Stern RC, Doershuk CF, Boat TF, Tucker AS, Primiano FP Jr, Matthews LW (1976): Course of cystic fibrosis in Black patients. J Pediatr 89:412-417.

Trowsdale J, Lee J, Carey J, Grosveld F, Bodmer J, Bodmer WF (1983): Sequences related to HLA-DRa chain on human chromosome 6: restriction enzyme polymorphism detected with $\mathrm{DCa}$ chain probes. Proc Natl Acad Sci USA 80:1972-1976.

Tsui L-C, Buchwald M, Barker D, Braman JC, Knowlton R, Schumm JW, Eiberg H, Mohr J, Kennedy D, Plavsic N, Zsiga M, Markiewicz D, Akots G, Brown V, Helms C, Gravins T, Parker C, Rediker K, Donis-Keller H (1985): Cystic fibrosis locus defined by a genetically linked polymorphic DNA marker. Science 239:1054-1057.

Tuomilehto-Wolf E, Cepaitis Z, Tuomilehto J, Luonamaa R (1989): New susceptibility haplotype for type 1 diabetes. Lancet 2:299-302.

Vidaud M, Kitzis A, Ferec C, Bozon D, Dumur V, Giraud G, David F, Pascal O, Auvinet M, Morel Y, Andre J, Chomel JC, Saleun JP, Farriaux JP, Roussel P, Labbe A, Dastugue B, Lucotte G, Monnier N, Foucaud P, Goossens M, Feingold J, Kaplan JC (1989): Confirmation of linkage disequilibrium between haplotype $\mathrm{B}(\mathrm{XV}-2 \mathrm{c}$, allele 1 ; KM-19, allele 2) and cystic fibrosis allele in the French population. Hum Genet 81:183-184.

Wainwright BJ, Scambler PJ, Schmidtke J, Watson EA, Law H-Y, Farrall M, Cooke HJ, Eiberg H, Williamson R (1985): Localization of eystic fibrosis locus to human chromosome 7 cen-q22. Nature 318:384-385.

Welsh MJ, Liedtke CM (1988): Chloride and potassium channels in cystic fibrosis airway epithelia. Nature 322:467-470.

White R, Woodward S, Leppert M, O'Connell P, Hoff M, Jerbst J, Lalouel J-M, Dean M, Vande Woude G (1985): A closely linked genetic marker for cystic fibrosis. Nature 318:382-384.

Wilkin TJ, Stutchfield P, Smith CS, Heaf DP (1987): Autoimmunity, diabetes, and cystic fibrosis. Lancet 2:157.

Wood B, Boat TF, Doershuk CF (1976): State of the art: cystic fibrosis. Am Rev Respir Dis 113:833-878. 